\author{
"Mircea cel Batran" Naval Academy Scientific Bulletin, Volume XX - 2017 - Issue 2 \\ The journal is indexed in: PROQUEST / DOAJ / Crossref / EBSCOhost/ INDEX COPERNICUS/ OAJI / DRJI I \\ JOURNAL INDEX / I2OR / SCIENCE LIBRARY INDEX / Google Scholar / Academic Keys / ROAD Open \\ Access I Academic Resources / Scientific Indexing Services / SCIPIOI JIFACTOR
}

\title{
THE UTILITY OF MOTOR ACTIVITIES IN DEVELOPING COORDONATION AND MOBILITY AT STUDENTS
}

\author{
Marcel POMOHACI ${ }^{1}$ \\ Sabin SOPA ${ }^{2}$ \\ ${ }^{1}$ Associate Professor PhD, "Lucian Blaga" University, Department of Environmental Science, Physics, \\ Physical Education and Sport, Ion Ratiu Street, No. 5-7, Sibiu, Romania \\ ${ }^{2}$ PhD Student, National University of Physical Education and Sport, Constantin Noica Street, No. 140, \\ Sector 6, Bucharest, Romania sopa sabin@yahoo.com
}

\begin{abstract}
The present study aims to analyze the importance of motor activities in developing speed coordination and joint mobility in primary school pupils. Student samples were divided into two groups, the first - the experimental group consisted of 25 students aged $10 \pm 2.1$ years, 13 boys and 12 girls, followed a specific program with agonist content, play and initiation in sports games; and the second group, the control group, consisted of 25 students aged $10 \pm 1.8$ years, 14 boys and 11 girls, a group that followed the classical curriculum of physical education and sports.

The motor tests used in the present study focused on the analysis of the speeding coordination indices (Illinois test, T-test, Cross test, Box Drill, AFL Agility test, Arrowhead test) and mobility tests (Sit and reach test, The mobility test of the inguinal area, the mobility test grasp the hands behind).

The results of the motor tests showed that the students in the experimental group had better performances than those in the control group at the motor tests performed at the final test, indicating the effectiveness of the programs with agonistic, play and initiation in sports games. Differences in final testing among student groups were significant in all motor tests $(p<0.05)$.

Conclusions have shown that the research hypothesis was valid, so we can say that inclusion of programs with agonistic and initiation in sports games can positively influence the student's motor performance at this age.
\end{abstract}

Keywords: motor activities, physical education and sport, coordination, mobility.

Introduction Physical education specialists, as well as the field of psychology, sociology, pedagogy, and medicine, have set goals, each in the area of their activity. There are no major differences between these approaches. Thus, physical education and sport must meet the following set of general objectives: maintaining an optimal health status and increasing the work and life skills of those practicing physical education and sports; the development of basic and specific motor skills; forming the right habit of conscious practicing exercises, both in an organized and independent setting, especially in leisure time; the formation of a wide system of motor skills and basic skills, but also its use in the sporting field; the effective contribution to the development of intellectual, civic, moral and intellectual traits and qualities, etc. [1]

Also, sports activities develop communication, intergroup relationships, and group cohesion. We can demonstrate that motor activities can develop group cohesion positive intergroup relationships development, the discovery of group leader and most importantly integrate and reintegrate children into the social group. Group cohesion is very important in the evolution of school performance as a group, therefore in groups where we can find

DOI: 10.21279/1454-864X-17-12-013

positive relationships as sympathy, friendships and cooperation the work efficiency is greater.[2] Motor activities can provide at this level of proximity necessary to meet the need to develop new relationships, so after some authors the wide variety of working means in motor activities can provide "personalized routes" carefully managed by specialists so that the moment of satisfaction corresponds to the long-term health benefits, social efficiency, social success, etc.[3]

The physical education and sports process combine both training and education in a balanced way so as to form complex, harmoniously developed and socially integrated personalities. Through physical education activities, there is a balanced transition that helps develop and maximize the human, mental, and social potential of the human individual.

Practicing sports activities systematically and regularly contributes to eliminating or diminishing shortcomings related to the somatic profile at the functional level of the body, supporting motivation for movement, controlling emotions, reducing stress, planning and organizing professional activities and leisure, developing intragroup relationships, improving communication and socialization.

Socialization through sport is a process of social integration through communication, understanding, and cooperation, with an 


\section{"Mircea cel Batran" Naval Academy Scientific Bulletin, Volume XX - 2017 - Issue 2 \\ The journal is indexed in: PROQUEST I DOAJ / Crossref / EBSCOhost/ INDEX COPERNICUSI OAJI / DRJI I JOURNAL INDEX I I2OR / SCIENCE LIBRARY INDEX / Google Scholar / Academic Keys / ROAD Open Access I Academic Resources / Scientific Indexing Services / SCIPIOI JIFACTOR}

interactive role for conflict resolution. So, it is structured on cognitive, affective and motivational constructions, as well as on the representations, behaviors, and performance of sports groups.[4] Situational factors are important for the cohesion of the group like living close to each another, sharing the same hobbies and activities, the same uniforms or clothing, group rituals etc.[5]

Motor activities of particular complexity, through structure and functionality, physical education and sport are constantly revealing new valences with implications for the development of the human being and society in general. Among the constant concerns of specialists in the field are the ones related to the contribution of physical education and sport to the process of socialization and social integration of the individual. [6]

Besides family, the first and most important social group, other groups contribute to the socialization of individuals: schoolmates, friends group and later professional staff. One of the ways that socialization within the group of friends or colleagues is performed is sports. Individuals learn through sport to work together, to assume certain roles within the group and to define themselves within the group. [7]

Sports cultivates team spirit and increases selfconfidence. Undoubtedly, the greatest gain of socialization in sport is that it develops within us the idea of social belonging and team spirit.[8] Physical education contains a multitude of different teaching systems, means, methods and technologies that meet the requirements of the subject categories, responding to their physical development needs, to meet the demands of the professions and maintain the level of health and physical fitness.

Another view on motor activities suggests that they are a "bridge between sedentary life and active life" which "is associated with other types of motor activities" as stretching contributes to improving the mobility and flexibility of the muscular system and contributes to relaxation by improving the quality of life of those involved in activities [9].

Motor activities are often associated with a healthy lifestyle, being an "important link to lifestyle, which involves making choices, according to your own choices, several times a week, moving to enjoy, to consume energy and to produce satisfaction".[10]

Socialization through sport is a complex process through which individuals learn skills, attitudes, values, and modes of behavior that enable them to function in a particular culture. These modes of behavior are taught in institutions such as school or family. [11]

The purpose of the study
This research aims to demonstrate that motor activities contribute to the harmonious physical development of students, the development of speed coordination and mobility. Thus, we want to propose and verify some training programs that contain agonistic motor skills and initiation systems in sports games in primary school pupils, aiming at the creation of didactic situations requiring the degree of conscious and active participation.

\section{Research objectives}

The aim of the research was to apply programs of agonistic and initiation in sports games and to identify the progress of students in the development of speed coordination and joint mobility.

\section{Research hypothesis}

Applying training programs that include agonistic and initiation means in sports games, determine the active-conscious participation of student in lessons, resulting in biomotricaccumulation and development of speed coordination and joint mobility.

\section{Methods of research}

The research methods used in experimental research were the following: the study of the specialized bibliography, experimental method (coordination and mobility tests), observation method.

\section{Speed coordination tests Coordination test Illinois}

Conducting the test: The length of the route is 10 meters (the distance between the start and the finish line) and the width is 5 meters. Four poles are used to mark the starting line, the finish line, and the two points to bypass. Four more poles are placed at the center of the route at equal distances between them. Each pole in the center has a distance from the other of 2.5 meters. Subjects have to run from the facially leaning position at the "go" signal in the direction indicated on the route without breaking down any pole 
"Mircea cel Batran" Naval Academy Scientific Bulletin, Volume XX - 2017 - Issue 2

The journal is indexed in: PROQUEST I DOAJ / Crossref / EBSCOhost/ INDEX COPERNICUSI OAJI / DRJI I JOURNAL INDEX I I2OR / SCIENCE LIBRARY INDEX / Google Scholar / Academic Keys I ROAD Open Access I Academic Resources / Scientific Indexing Services / SCIPIOI JIFACTOR

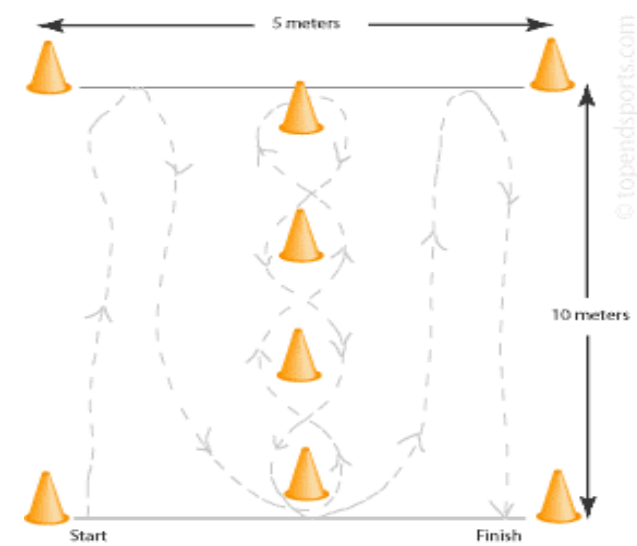

Figure No. 1 - Speed coordination test Illinois[12]

\section{Coordination T-test}

Conducting the test: Place four poles as in the following diagram ( $5 \mathrm{~m}$ between the $\mathrm{B}, \mathrm{C}, \mathrm{D}$ and $10 \mathrm{~m}$ between the $A$ and $B$ poles). The subject starts at the pole A. At the start command, the stopwatch starts and the evaluated subject starts in speed running forward to the B-pole and touches the base of it with his right hand. After that, it performs lateral movement until the C-pole, also touching the base of the pole this time with its left hand, then the subject moves through lateral movement to the D-pole and touches the base of the pole with its right hand. Afterward, it moves with lateral movement to the pole $B$ and taps the base of the pole with his left hand and then moving back to the pole $A$. The stopwatch stops when the subject passes through the pole $A$.

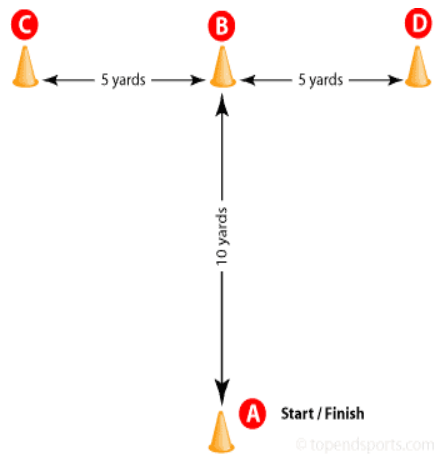

Figure No. 2 - Speed coordonation T-Test [13]

The speed coordination test in "cross" or "star" (Agility Cone)

Conducting the test: The poles are placed in the same way as in the adjacent image, with four rows placed in the shape of a diamond and one placed in the middle. Outside poles are located three meters from the center. The subject is seated crouched behind the middle pole touching it with his left hand, facing forward (pole 5). The subject turns around and runs right, touching with the right hand the pole from the right. Then he turns back, runs to the middle pole, touches it, and continues his path to the pole no. 3 , back to the center, then to the next pole no. 4 , back to the center, and finally runs to the finishing line at 5 . The subject is forced to touch the pole each time. The timer starts when the hand moves from the middle pole and stops when the chest passes the finish line. The subject rests for 3 minutes, then repeats the test, moving in the opposite direction (counterclockwise in the order 1-4-3-2-5).

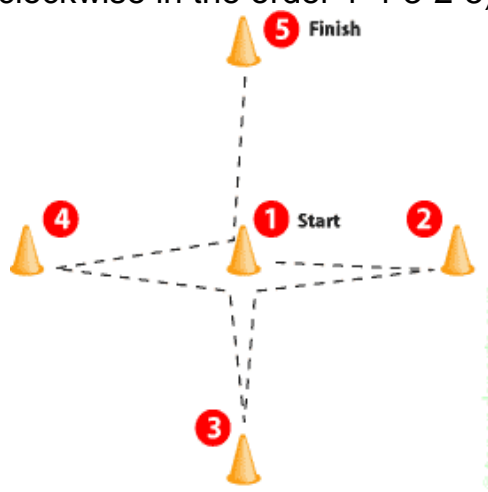

Figure No. 3 - The speed coordination test in "cross"[14]

\section{The "Box Drill" Coordination Test}

Conducting the test: four poles are placed in the shape of a square with a distance of 10 meters (see the diagram). The subject starts running from pole no. 1 , run up to pole no. 2 , then makes the lateral movement to pole no. 3 , then runs backwards to pole no. 4 and sprints to pole no. 1 .

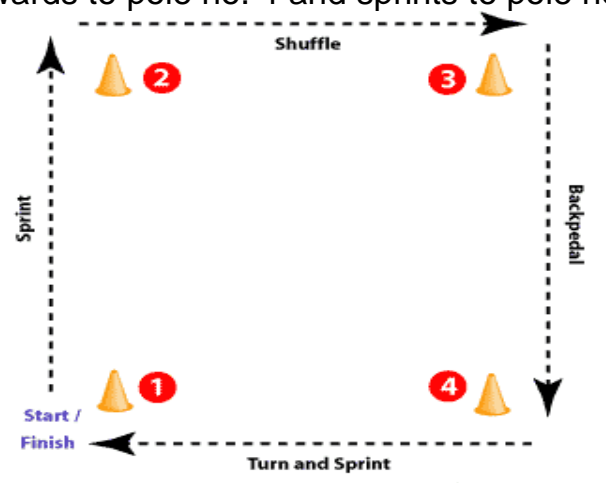

Figure No. 4 - The "Box Drill" Coordination Test [15]

\section{Speed coordination test AFL Agility}

Conducting the test: a zigzag path is set using 5 poles as in the picture below. Performance can be measured with a stopwatch; it is recommended after a proper warming at the route, but at a speed of about $50 \%$ of the possibilities, to get familiar with the route. The subject performs speed running throw the obstacles like in the next image 


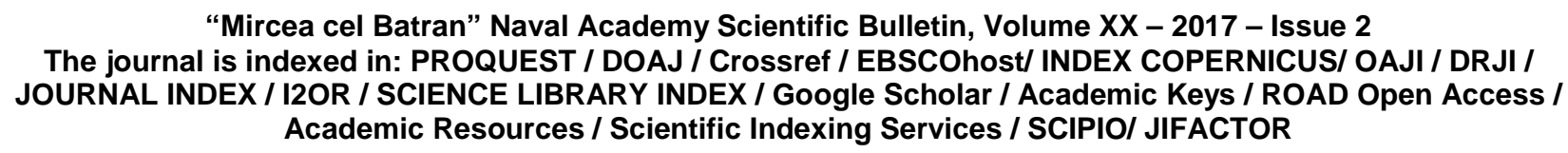

"Mircea cel Batran" Naval Academy Scientific Bulletin, Volume XX - 2017 - Issue 2

The journal is indexed in: PROQUEST I DOAJ / Crossref / EBSCOhost/ INDEX COPERNICUSI OAJI / DRJI I JOURNAL INDEX I I2OR / SCIENCE LIBRARY INDEX / Google Scholar / Academic Keys I ROAD Open Access I Academic Resources / Scientific Indexing Services I SCIPIOI JIFACTOR

and if he throws off one of the obstacles as shown in the next image the recording is interrupted and the route is rerun. Two attempts will be carried out with a 2-3 minute rest break.

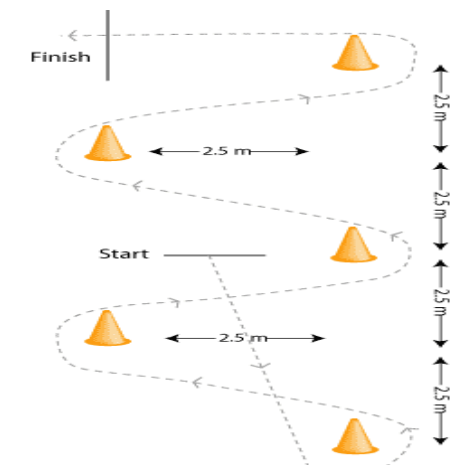

Figure No. 5 - Speed coordination test AFL Agility[16]

\section{"Arrowhead" Speed Coordination Test}

Conducting the test:The poles are placed as shown in the adjacent image, in the form of an arrow type, and a set of poles to mark the start and finish. The subject starts with the legs behind the starting line with a standing start. When he is ready, he runs with maximum speed to the middle pole (pole $A$ ), returns and runs toward pole $D$, bypassing it outward, then to the distal pole $B$ and back to the finish line. The subject has 2 route repetitions, one on the left and one on the right. The test is not recorded if the subject goes over a pole rather than bypassing it or breaking it down.

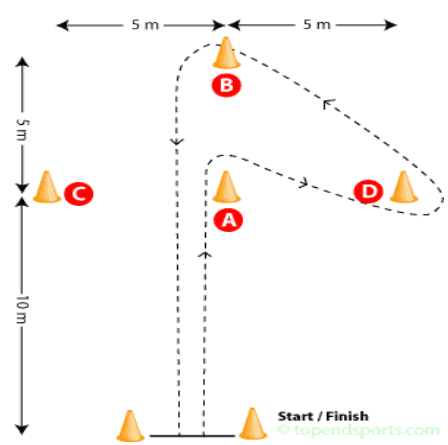

Figure No. 6 - Arrowhead speed coordination test [17]

\section{Mobility tests}

\section{The mobility test "stretch from sitting"}

Conducting the test: This test involves placing the subject on the ground with the legs stretched forward without shoes. The sole of the feet is stretched behind the measuring device. Both knees should be locked and held down on the floor - the consultant can help support the knees. With the palms stretched down to the toes, the subject tries to stretch before reaching as far as the tip of the legs. Make sure your hands stay at the same level, not one farther than the other. After a few exercise attempts, the subject stretches and holds the position for two to three seconds until the performance is recorded. Also, make sure the subject does not swing when stretching.

Figure No. 7 -The mobility test "stretch from sitting"[18]

Table No. 1 - The interpretations of the results of the mobility test "stretch from sitting"[19]

\begin{tabular}{|c|c|c|}
\hline Grade & male & female \\
\hline Super & $>+27$ & $>+30$ \\
\hline Excellent & +17 to +27 & +21 to +30 \\
\hline Very good & +6 to +16 & +11 to +20 \\
\hline Good & 0 to +5 & +1 to +10 \\
\hline Satisfactory & -8 to -1 & -7 to 0 \\
\hline Unsatisfactory & -20 to -9 & -15 to -8 \\
\hline Very poor & $<-20$ & $<-15$ \\
\hline
\end{tabular}

The mobility of the groin area (groin flexibility) Conducting the test: The subject is in the position with the knees bent, the toes fixed and the feet bent on the ground. Allow your knees to descend as much as possible, keeping the toes fixed. The toes of the feet must stick together. Hold your toes with the feet attached with both hands, and pull the heels of your legs as far as you can in the groin area. The distance from the heel to the groin area is measured

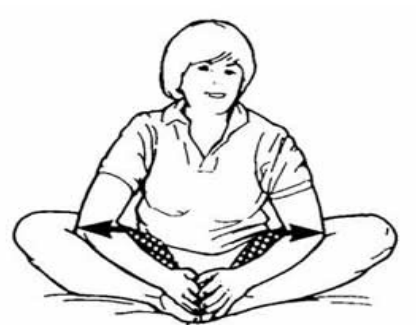

Figure No. 8-The mobility of the groin area [20]

Table No. 2 - The interpretation of the results at the mobility of the groin area [21]

\begin{tabular}{|l|l|}
\hline Grade & Score \\
\hline
\end{tabular}

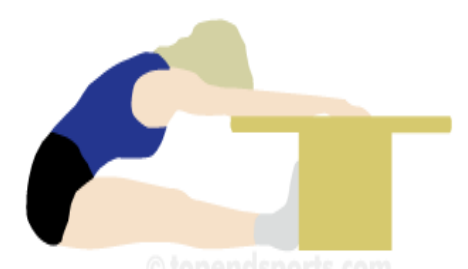


"Mircea cel Batran" Naval Academy Scientific Bulletin, Volume XX - 2017 - Issue 2

The journal is indexed in: PROQUEST I DOAJ / Crossref / EBSCOhost/ INDEX COPERNICUSI OAJI / DRJI I JOURNAL INDEX / I2OR / SCIENCE LIBRARY INDEX / Google Scholar / Academic Keys / ROAD Open Access I Academic Resources / Scientific Indexing Services / SCIPIO/ JIFACTOR

\begin{tabular}{|l|l|}
\hline Excellent & $5 \mathrm{~cm}$ \\
\hline Very good & $10 \mathrm{~cm}$ \\
\hline Good & $15 \mathrm{~cm}$ \\
\hline Satisfactory & $20 \mathrm{~cm}$ \\
\hline Unsatisfactory & $25 \mathrm{~cm}$ \\
\hline
\end{tabular}

The "gripping hands behind" test

Conducting the test: This test is carried out from the standing position. The subject puts a hand behind his head and back over his shoulder, reaching as far as possible in the middle of his back, his palm touching the body with his fingers pointing down. Place the other arm back, with your palm facing outwards and your fingers upward, and try to get up as far as possible by trying to touch or overlap the middle fingers of both hands. If the fingertips reach, the score is zero. If it does not touch, the distance between fingertips is measured.

Table No. 3 - The interpretation of the results at the "gripping hands behind" test[22]

\begin{tabular}{|c||c|c|c||}
\hline Grade & Very good & Good & Poor \\
\hline \hline Description & $\begin{array}{c}\text { Fingers touch and even } \\
\text { get caught }\end{array}$ & Fingers just touch & $\begin{array}{c}\text { The fingers do not touch, the } \\
\text { difference being greater than 2 cm }\end{array}$ \\
\hline \hline & &
\end{tabular}

\section{Research sample}

The research subjects came from the Secondary School Nr. 179 in Sector 1, Bucharest, representing two Classes of IV present in the school in the 2015-2016 school year.

We divided the two classes in: an experiment group (class IV A or Group A) and a control group (Class IV B or Group B).

The experiment group A was formed by:

-25 students with the age between 10 and 12 years old, 13 boys and 12 girls;

The control group B was formed by:

-25 students with the age cu between 10 and 12 years old, 13 boys and 11 girls

Table No. 1 - The distribution of the experimental and control group

\begin{tabular}{|c|c|c|c|c|}
\hline \multirow{2}{*}{ Group } & \multicolumn{2}{|c|}{ Number of children } & \multirow{2}{*}{ Age } & Experiment/Control \\
\cline { 2 - 3 } & Girls & Boys & & \\
\hline Class a II-a A & 12 & 13 & $8 \pm 1.2$ years & experimental group \\
\hline Class a II-a B & 11 & 14 & $8 \pm 1.5$ years & control group \\
\hline
\end{tabular}


"Mircea cel Batran" Naval Academy Scientific Bulletin, Volume XX - 2017 - Issue 2

The journal is indexed in: PROQUEST I DOAJ / Crossref / EBSCOhost/ INDEX COPERNICUSI OAJI / DRJI I JOURNAL INDEX / I2OR / SCIENCE LIBRARY INDEX / Google Scholar / Academic Keys / ROAD Open Access I Academic Resources / Scientific Indexing Services I SCIPIOI JIFACTOR

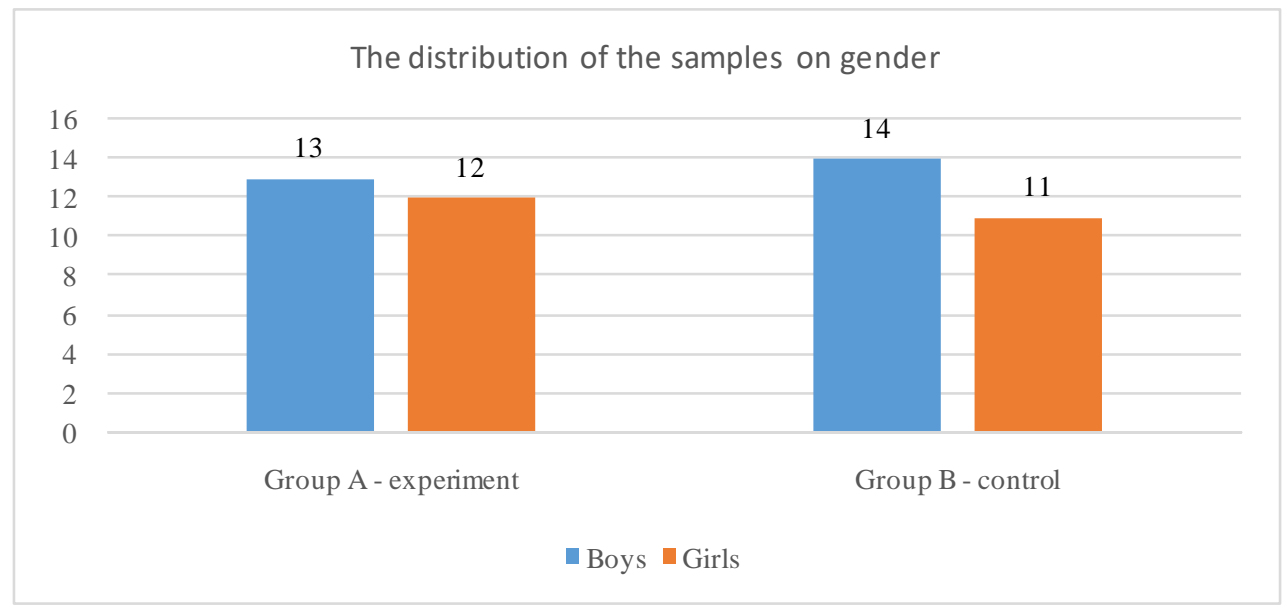

Results

Figure No. 9 - The distribution of the samples on gender

\section{RECORDING, PROCESSING AND INTERPRETATION OF THE INITIAL DATA OBTAINED IN THE TESTS OF ASSESSMENT OF SPEED COORDINATION AND MOBILITY}

Table No. 5 - Evaluation of speed and mobility coordination at Experiment Group - Initial testing

\begin{tabular}{|c|c|c|c|c|c|c|c|c|}
\hline $\begin{array}{c}\text { Statistical } \\
\text { indicators }\end{array}$ & $\begin{array}{c}\text { TC } \\
\text { Illinois }\end{array}$ & $\begin{array}{c}\text { TC } \\
\text { Test-T }\end{array}$ & $\begin{array}{c}\text { TC } \\
\text { Cross }\end{array}$ & $\begin{array}{c}\text { TC } \\
\text { AFL }\end{array}$ & $\begin{array}{c}\text { TC } \\
\text { Arrow }\end{array}$ & TM1 & TM2 & TM3 \\
\hline $\mathbf{X}$ & 24.68 & 18.76 & 11.40 & 12.88 & 15.60 & 4.24 & 13.36 & 3.88 \\
\hline $\mathbf{M}_{\mathbf{e}}$ & 25.00 & 19.00 & 11.00 & 13.00 & 15.00 & 4.00 & 14.00 & 4.00 \\
\hline $\mathbf{M}_{\mathbf{o}}$ & 24.00 & 18.00 & 10.00 & 12.00 & 14.00 & 3.00 & 15.00 & 4.00 \\
\hline $\mathbf{A}_{\mathbf{s}}$ & 2.61 & 1.96 & 1.73 & 1.56 & 2.65 & 1.20 & 2.31 & 1.45 \\
\hline $\mathbf{V a r}_{\mathbf{m}}$ & 6.81 & 3.86 & 3.00 & 2.44 & 7.00 & 1.44 & 5.32 & 2.11 \\
\hline $\mathbf{A}_{\mathbf{m}}$ & 10.00 & 8.00 & 7.00 & 5.00 & 9.00 & 4.00 & 7.00 & 5.00 \\
\hline $\mathbf{M i n}$ & 19.00 & 15.00 & 9.00 & 11.00 & 13.00 & 3.00 & 10.00 & 1.00 \\
\hline $\mathbf{M a x}$ & 29.00 & 23.00 & 16.00 & 16.00 & 22.00 & 7.00 & 17.00 & 6.00 \\
\hline $\mathbf{C}_{\mathbf{v}}$ & 0.11 & 0.10 & 0.15 & 0.12 & 0.17 & 0.28 & 0.17 & 0.37 \\
\hline Skewness & -0.63 & 0.08 & 1.05 & 0.64 & 1.12 & 0.91 & -0.26 & -0.57 \\
\hline Kurtosis & -0.07 & -0.21 & 1.12 & -0.55 & 0.28 & 0.37 & -1.49 & -0.05 \\
\hline
\end{tabular}

Table No. 6 - Evaluation of speed and mobility coordination at Control Group - Initial testing

\begin{tabular}{|c|c|c|c|c|c|c|c|c|}
\hline $\begin{array}{c}\text { Statistical } \\
\text { indicators }\end{array}$ & $\begin{array}{c}\text { TC } \\
\text { Illinois }\end{array}$ & $\begin{array}{c}\text { TC } \\
\text { Test-T }\end{array}$ & $\begin{array}{c}\text { TC } \\
\text { Cross }\end{array}$ & $\begin{array}{c}\text { TC } \\
\text { AFL }\end{array}$ & $\begin{array}{c}\text { TC } \\
\text { Arrow }\end{array}$ & TM1 & TM2 & TM3 \\
\hline $\mathbf{X}$ & 27.36 & 21.04 & 11.92 & 14.84 & 14.36 & 4.76 & 14.48 & 5.92 \\
\hline $\mathbf{M}_{\mathbf{e}}$ & 27.00 & 21.00 & 12.00 & 14.00 & 14.00 & 5.00 & 15.00 & 6.00 \\
\hline $\mathbf{M}_{\mathbf{o}}$ & 26.00 & 21.00 & 12.00 & 14.00 & 15.00 & 4.00 & 11.00 & 5.00 \\
\hline $\mathbf{A}_{\mathbf{s}}$ & 2.34 & 2.30 & 1.87 & 2.23 & 2.14 & 1.16 & 2.74 & 1.32 \\
\hline $\mathbf{V a r}$ & 5.49 & 5.29 & 3.49 & 4.97 & 4.57 & 1.36 & 7.51 & 1.74 \\
\hline $\mathbf{A}_{\mathbf{m}}$ & 10.00 & 9.00 & 7.00 & 8.00 & 8.00 & 5.00 & 9.00 & 5.00 \\
\hline Min & 24.00 & 18.00 & 9.00 & 12.00 & 11.00 & 3.00 & 10.00 & 4.00 \\
\hline Max & 34.00 & 27.00 & 16.00 & 20.00 & 19.00 & 8.00 & 19.00 & 9.00 \\
\hline $\mathbf{C}_{\mathbf{v}}$ & 0.09 & 0.11 & 0.16 & 0.15 & 0.15 & 0.24 & 0.19 & 0.22 \\
\hline Skewness & 0.96 & 0.95 & 0.46 & 0.88 & 0.60 & 0.68 & -0.25 & 0.51 \\
\hline Kurtosis & 1.27 & 0.44 & -0.34 & -0.22 & 0.48 & 1.05 & -1.32 & -0.23 \\
\hline
\end{tabular}

\section{$X$ - Arithmetic mean}

TC Illinois - Coordination test "Illinois”

TC Test-T -Coordination „Test-T”

TC Cross - Coordination test "Incross"

TC AFL - Coordination test „AFL”

TM1 - Mobility test „stretch from sitting”

TM2 - Mobility test of the groin area

TM3 - Mobility test „gripping the hands behind”
$\mathrm{C}_{\mathrm{v}}-$ Coefficientof variability

$\mathrm{M}_{\mathrm{e}}-$ Median

$\mathrm{M}_{\mathrm{o}}-$ Module

$A_{s}-$ Standard deviation

Var - Variation

Am - Amplitude

Min - Minimum value

Max - Maximum value 
"Mircea cel Batran" Naval Academy Scientific Bulletin, Volume XX - 2017 - Issue 2

The journal is indexed in: PROQUEST / DOAJ / Crossref / EBSCOhost/ INDEX COPERNICUS/ OAJI / DRJI I JOURNAL INDEX / I2OR / SCIENCE LIBRARY INDEX / Google Scholar / Academic Keys / ROAD Open Access I Academic Resources / Scientific Indexing Services I SCIPIOI JIFACTOR

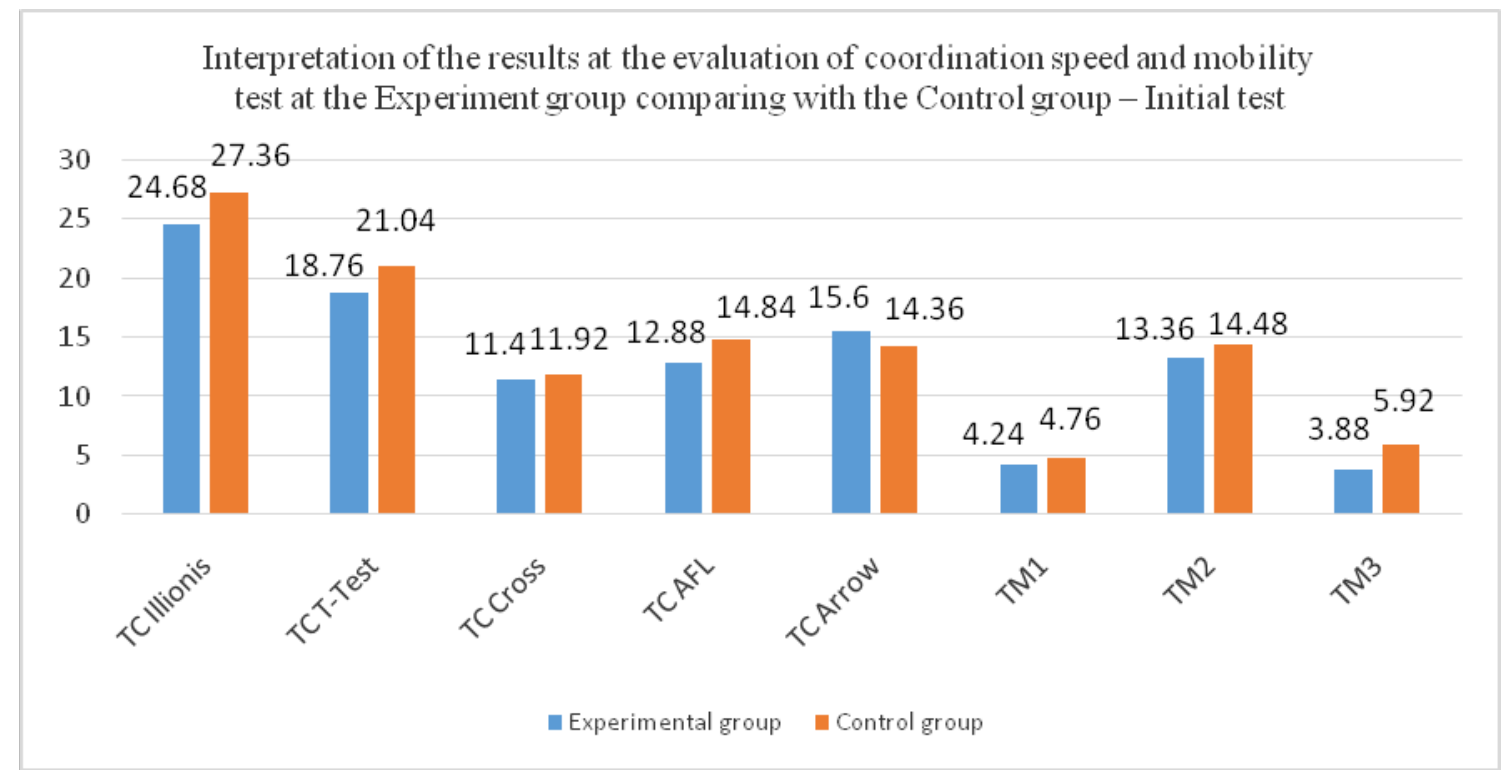

Figure Nr. 10 - Interpretation of the results at the evaluation of coordination speed and mobility test at the Experiment group comparing with the Control group - Initial test

In the evaluation of coordination and mobility, at the first test, the Illinois test, we recorded a difference of 2.68 seconds between the experiment group (24.68 sec.) and the control group (27.36 sec.). At the "T-test" test, we recorded a 2.28 second difference between the experiment group (18.76 sec.) and the control group (21.04 sec).

Regarding the "TC Cross" test, we found a difference of 0.52 seconds between the experiment group (11.40 sec.) and the control group (11.92 sec). At "TC AFL" testing, we recorded a difference of 1.96 seconds between the experiment group (12.88 seconds) and the control group (14.84 seconds).
At the "TC Arrow" test, we noticed a difference of 1.24 seconds between the experiment group (15.60 sec.) and the control group (14.36 sec).

At the mobility tests, at the first mobility test, we recorded a difference of $0.52 \mathrm{~cm}$ between the experiment group $(4.24 \mathrm{~cm})$ and the control group $(4.76 \mathrm{~cm})$. At the second mobility test, we recorded a difference of 1.12 $\mathrm{cm}$ between the experimental group (13.36 $\mathrm{cm})$ and the control group $(14.48 \mathrm{~cm})$.

As for the last mobility test, we recorded a difference of $2.04 \mathrm{~cm}$ between the experiment group $(3.88 \mathrm{~cm})$ and the control group (5.92 $\mathrm{cm})$.

\section{RECORDING, PROCESSING AND INTERPRETATION OF THE FINAL DATA OBTAINED IN THE TESTS OF ASSESSMENT OF SPEED COORDINATION AND MOBILITY}

Table No. 7 - Evaluation of speed and mobility coordination at Experiment Group - Final testing

\begin{tabular}{|c|c|c|c|c|c|c|c|c|}
\hline $\begin{array}{c}\text { Statistical } \\
\text { indicators }\end{array}$ & $\begin{array}{c}\text { TC } \\
\text { Illinois }\end{array}$ & $\begin{array}{c}\text { TC } \\
\text { Test-T }\end{array}$ & $\begin{array}{c}\text { TC } \\
\text { Cross }\end{array}$ & $\begin{array}{c}\text { TC } \\
\text { AFL }\end{array}$ & $\begin{array}{c}\text { TC } \\
\text { Arrow }\end{array}$ & TM1 & TM2 & TM3 \\
\hline $\mathbf{X}$ & 21.56 & 15.44 & 9.76 & 12.52 & 13.92 & 3.16 & 13.12 & 2.76 \\
\hline $\mathbf{M}_{\mathbf{e}}$ & 22.00 & 15.00 & 10.00 & 12.00 & 13.00 & 3.00 & 13.00 & 3.00 \\
\hline $\mathbf{M}_{\mathbf{o}}$ & 22.00 & 15.00 & 9.00 & 12.00 & 12.00 & 3.00 & 12.00 & 4.00 \\
\hline $\mathbf{A}_{\mathbf{s}}$ & 2.42 & 2.10 & 1.39 & 1.58 & 2.55 & 0.99 & 1.36 & 1.16 \\
\hline $\mathbf{V a r}$ & 5.84 & 4.42 & 1.94 & 2.51 & 6.49 & 0.97 & 1.86 & 1.36 \\
\hline $\mathbf{A}_{\mathbf{m}}$ & 9.00 & 8.00 & 6.00 & 6.00 & 9.00 & 4.00 & 4.00 & 4.00 \\
\hline $\mathbf{M i n}_{\text {Max }}$ & 17.00 & 12.00 & 7.00 & 10.00 & 11.00 & 2.00 & 11.00 & 1.00 \\
\hline $\mathbf{C}_{\mathbf{v}}$ & 26.00 & 20.00 & 13.00 & 16.00 & 20.00 & 6.00 & 15.00 & 5.00 \\
\hline Skewness & -0.11 & 0.14 & 0.14 & 0.13 & 0.18 & 0.31 & 0.10 & 0.42 \\
\hline Kurtosis & -0.45 & 0.21 & 0.57 & 0.88 & 1.21 & 1.07 & -0.02 & -0.01 \\
\hline
\end{tabular}


"Mircea cel Batran" Naval Academy Scientific Bulletin, Volume XX - 2017 - Issue 2

The journal is indexed in: PROQUEST I DOAJ / Crossref / EBSCOhost/ INDEX COPERNICUSI OAJI / DRJI I JOURNAL INDEX / I2OR / SCIENCE LIBRARY INDEX / Google Scholar / Academic Keys / ROAD Open Access I Academic Resources / Scientific Indexing Services / SCIPIOI JIFACTOR

Table No. 8 - Evaluation of speed and mobility coordination at Control Group - Final testing

\begin{tabular}{|c|c|c|c|c|c|c|c|c|}
\hline $\begin{array}{c}\text { Statistical } \\
\text { indicators }\end{array}$ & $\begin{array}{c}\text { TC } \\
\text { Illinois }\end{array}$ & $\begin{array}{c}\text { TC } \\
\text { Test-T }\end{array}$ & $\begin{array}{c}\text { TC } \\
\text { Cross }\end{array}$ & $\begin{array}{c}\text { TC } \\
\text { AFL }\end{array}$ & $\begin{array}{c}\text { TC } \\
\text { Arrow }\end{array}$ & TM1 & TM2 & TM3 \\
\hline $\mathbf{X}$ & 26.32 & 19.96 & 11.04 & 13.48 & 13.32 & 4.68 & 13.64 & 4.92 \\
\hline $\mathbf{M}_{\mathbf{e}}$ & 26.00 & 20.00 & 11.00 & 13.00 & 13.00 & 5.00 & 14.00 & 5.00 \\
\hline $\mathbf{M}_{\mathbf{o}}$ & 26.00 & 20.00 & 11.00 & 12.00 & 14.00 & 5.00 & 15.00 & 5.00 \\
\hline $\mathbf{A}_{\mathbf{s}}$ & 1.77 & 1.81 & 1.37 & 1.98 & 1.73 & 1.22 & 2.29 & 1.00 \\
\hline $\mathbf{V a r}$ & 3.14 & 3.29 & 1.87 & 3.93 & 2.98 & 1.48 & 5.24 & 0.99 \\
\hline $\mathbf{A}_{\mathbf{m}}$ & 7.00 & 6.00 & 5.00 & 8.00 & 7.00 & 5.00 & 7.00 & 4.00 \\
\hline $\mathbf{M i n}_{\mathbf{M a x}}$ & 24.00 & 17.00 & 9.00 & 10.00 & 11.00 & 2.00 & 10.00 & 3.00 \\
\hline $\mathbf{C}_{\mathbf{v}}$ & 31.00 & 23.00 & 14.00 & 18.00 & 18.00 & 7.00 & 17.00 & 7.00 \\
\hline Skewness & 1.08 & 0.09 & 0.12 & 0.15 & 0.13 & 0.26 & 0.17 & 0.20 \\
\hline Kurtosis & 1.10 & -0.47 & 0.56 & 0.77 & 1.10 & -0.08 & -0.31 & 0.45 \\
\hline
\end{tabular}

$X$ - Arithmetic mean

$\mathrm{C}_{\mathrm{v}}$ - Coefficient of variability

TC Illinois - Coordination test „Illinois”

TC Test-T - Coordination „Test-T”

TC Cross - Coordination test „In cross"

TC AFL - Coordination test „AFL”

TM1 - Mobility test „stretch from sitting”

TM2 - Mobility test of the groin area

TM3 - Mobility test „gripping the hands behind"

$\mathrm{M}_{\mathrm{e}}-$ Median

$\mathrm{M}_{\mathrm{o}}$ - Module

$A_{s}$ - Standard deviation

Var - Variation

Am - Amplitude

Min - Minimum value

Max - Maximum value

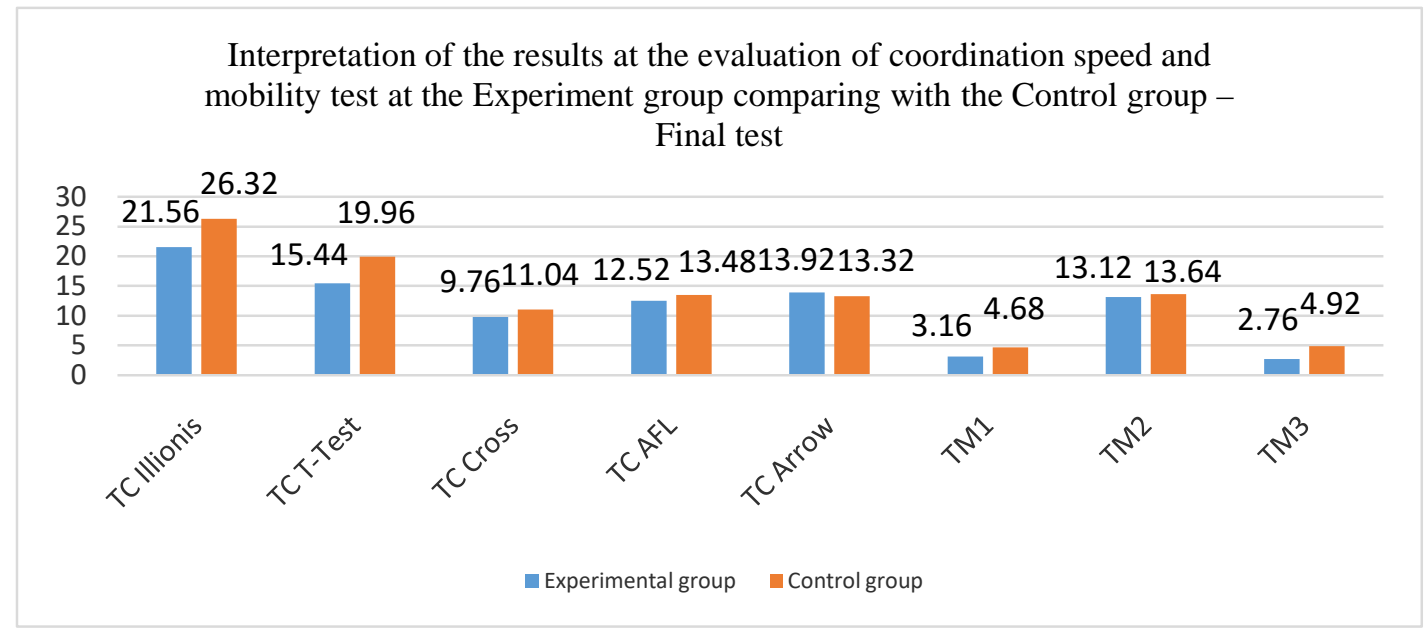

Figure Nr. 11 - Interpretation of the results at the evaluation of coordination speed and mobility test at the Experiment group comparing with the Control group - Final test

In the evaluation of coordination and mobility, in the first test, the "Illinois test", we recorded a difference of 4.76 seconds between the experiment group (21.56 sec.) and the control group (26.32 sec.). At the "T-test" test, we recorded a 4.52 second difference between the experiment group (15.44 sec.) and the control group (19.96 sec).

As for the "TC Cross" test, we found a difference of 1.28 seconds between the experiment group (9.76 sec.) and the control group (11.04 sec). At TC AFL we recorded a 0.96 second difference between the experiment group (12.52 seconds) and the control group (13.48 seconds).
At "TC Arrow" we noticed a 0.60 second difference between the experiment group (13.92 sec.) and the control group (13.32 sec).

In the mobility tests, the mobility test no. 1 we recorded a difference of $1.52 \mathrm{~cm}$ between the experimental group $(3.16 \mathrm{~cm})$ and the control group $(4.68 \mathrm{~cm})$. At the second mobility test, we recorded a difference of $0.52 \mathrm{~cm}$ between the experimental group $(13.12 \mathrm{~cm})$ and the control group $(13.64 \mathrm{~cm})$.

As for the last mobility test, we recorded a difference of $2.16 \mathrm{~cm}$ between the experiment group $(2.76 \mathrm{~cm})$ and the control group (4.92 $\mathrm{cm})$. 


\section{"Mircea cel Batran" Naval Academy Scientific Bulletin, Volume XX - 2017 - Issue 2 The journal is indexed in: PROQUEST I DOAJ / Crossref / EBSCOhost/ INDEX COPERNICUSI OAJI / DRJI I JOURNAL INDEX / I2OR / SCIENCE LIBRARY INDEX / Google Scholar / Academic Keys / ROAD Open Access I Academic Resources / Scientific Indexing Services I SCIPIOI JIFACTOR}

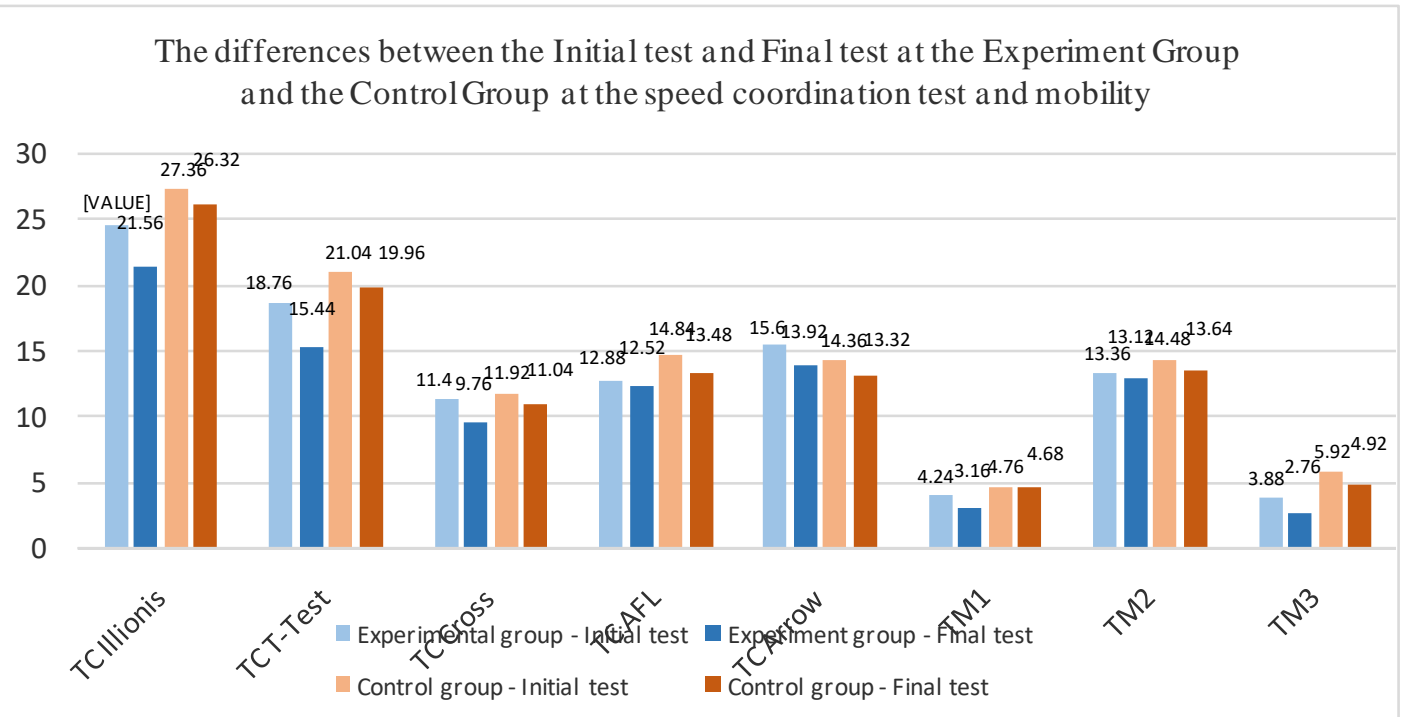

Figure No. 12 - The differences between the Initial test and Final test at the Experiment Group and the Control Group at the speed coordination test and mobility

Analyzing the differences in the initial and final evaluations of speed coordination and mobility in the two groups, experiment, and control, we can see the following:

- On the first test, the "TC Illinois" test in the experimental group, we recorded a time improvement of $-3.12 \mathrm{sec}$ and a $12.64 \%$ progress rate superior to the control group that achieved a decrease in execution time of -1.04 and a rate of progress of $3.83 \%$; applying the significance $\mathrm{T}$ test we observed that the value of $t$ was -7.94069 and $p$ of $0.00001, p<0.05$, indicating a significant difference between the two groups of students.

- For the coordination "T-test", we obtained a better time in the experimental group with -3.32 sec and a rate of progression of $17.70 \%$ compared to the control group where we obtained an improvement in the run time of $-1.08 \mathrm{sec}$ and a progress rate of $5.13 \%$; applying the significance T-test, we noticed that the value of $t$ was -8.13743 and $p$ of $0.00001, p<0.05$, indicating a significant difference between the two groups of students.

- For the coordination "TC Cross" test, we recorded a time improvement of $-1.64 \mathrm{sec}$ and a progress rate of $14.39 \%$ for the experimental group, compared to the control group where we achieved a better time of $-0.88 \mathrm{sec}$ and a rate of $7.69 \%$ progress; by applying the significance $\mathrm{T}$ test, we noticed that the value of $t$ was -3.27739 and $p$ of $0.000976, p<0.05$, indicating a significant difference between the two groups of students.

- At the coordination "TC AFL" testing showed an improvement in the experimental time of $-0.36 \mathrm{sec}$ and a $2.80 \%$ progress rate lower than the control group that achieved a better time of $-1.36 \mathrm{sec}$ and a progress rate of $7.30 \%$; applying the significance T-test we observed that the value of $t$ was -1.89196 and $p$ of $0.032269, p<0.05$, indicating a significant difference between the two groups of students.

- For the coordination "TC Arrow" test in the experimental group, we notice a time improvement of $-1.68 \mathrm{sec}$ and a progress rate of $10.77 \%$ compared to the control group where we recorded a better time of $-1.04 \mathrm{sec}$ and a progress rate of $7.30 \%$; by applying the significance T-test, we noticed that the value of $t$ was 0.97487 and that of $p$ of $0.167256, p<0.05$, indicating an insignificant difference between the two groups of students.

- at the first mobility test TM1 in the experimental group we see an increase in mobility of $1.08 \mathrm{~cm}$ and a progress rate of $25.47 \%$ compared to the control group where we recorded a better result of $0.08 \mathrm{~cm}$ and a progress rate of $1.67 \%$, applying the T-test significance test, we noticed that its value was -4.85546 , and $p$ of $0.00001, p<0.05$, indicating a significant difference between the two groups of students.

- at the second mobility test "TM2" in the experimental group there was an improvement of $0.24 \mathrm{~cm}$ and a rate of progression of $1.80 \%$, inferior to the result of the control group where we observed an improvement of $0.84 \mathrm{~cm}$ and a rate of progress of $5.72 \%$, applying the significance $\mathrm{T}$ test, we noticed that its value was -0.97576 , and $p$ was $0.167037, p<0.05$, indicating an insignificant difference between the two groups of students.

- At the last mobility test TM3, in the experimental group, we noticed an improvement of $1.12 \mathrm{~cm}$ and a progress rate of $28.87 \%$ compared to the control group where an improvement of $1 \mathrm{~cm}$ was recorded and a rate of progression of $17.44 \%$; applying the significance 


\begin{abstract}
"Mircea cel Batran" Naval Academy Scientific Bulletin, Volume XX - 2017 - Issue 2
The journal is indexed in: PROQUEST / DOAJ / Crossref / EBSCOhost/ INDEX COPERNICUS/ OAJI / DRJI I

JOURNAL INDEX / I2OR / SCIENCE LIBRARY INDEX / Google Scholar / Academic Keys I ROAD Open Access I Academic Resources / Scientific Indexing Services I SCIPIOI JIFACTOR
\end{abstract}

T-test, we noticed that the value of $t$ was 7.04514, and $p$ of $0.00001, p<0.05$, indicating a significant difference between the two groups of students.

\title{
Conclusions
}

Including agonistic means and initiating in sports games in the training programs of primary school students positively influences the level of development of bio-motor capacity and physical development, we can say that the hypothesis has been validated by the results of the tests and final measurements, there are significant differences between the two tests in the experimental group, and we also we can find significant differences between the final results compared to the control group, the level of speed coordination and joint mobility increased from the first test to the final one.

\section{Bibliography}

[1] Cârstea, G., (2000) - „The theory and methodic of physical education and sport”,Editor AN-DA, Bucharest;

[2] Sopa I. S., Pomohaci, M., (2014), Developing Cohesion in Sportive Group through Socializing Means of Motor Activities. Published in: Medimond by Editografica, Bologna, page 135.

[3] Bota, A., (2007) - „Kinesiology”, Editor Didacticand Pedagogic R.A. Bucharest, p. 89;

[4] Sopa, I. S., Pomohaci, M., (2014), Study regarding the impact of sport competitions on student's socialization. Published in European Scientific Journal, Volume 10, No 26.

[5] Sopa, I. S., Szabo, D. A., (2014), Study regarding the importance of developing group cohesion in a volleyball team. Published in: Procedia Social and Behavioral Sciences, Volume 180C, 5 May 2015, page 1343.

[6] Stănescu, M.,(2000) - „Physical education and sport - factors at the socializing process”, ANEFS, Annual session of papers and scientific communications 9-10 march 2000; page 298.

[7] Sopa, I. S., (2014), The socializing role of motor activities at primary school level. Bulletin of the Transylvania Brasov, Vol. 7 (56) No. 2.

[8] Gavriluţă, C., Gavriluţă, N., (2005) - „Sociologyof sport”, EditorPolirom, laşi, page 39;

[9] Macovei, S., (2012) - „Stretching”, Ed. AFIR, Bucharest.

[10] Grigore, V., (2007) - „Physical exercises. Active factor for preventing aging and degenerative disease”, Editor Didacticand Pedagogic, Bucharest, page 14.

[11] Sopa, I. S., Pomohaci, M., (2014), Socialization through sport, effects of team sports on students at primary school level. Published in: Medimond by Editografica, Bologna, page 351.

[12] http://www.topendsports.com/testing/tests/illinois.htm

[13] http://www.topendsports.com/testing/tests/t-test.htm

[14] http://www.topendsports.com/testing/tests/agility-cone-drill.htm

[15] http://www.topendsports.com/testing/tests/box-drill.htm

[16] http://www.topendsports.com/testing/tests/agility-afl.htm

[17] http://www.topendsports.com/testing/tests/arrowhead-agility-drill.htm

[18] http://www.topendsports.com/testing/tests/sit-and-reach.htm

[19] http://www.topendsports.com/testing/tests/groin-flexibility.htm

[20] http://www.topendsports.com/testing/tests/back-scratch.htm 